\title{
Incidence of Intestinal Parasites among Food Handlers (Hawkers) around the University of Nigeria Teaching Hospital Enugu, Enugu State, Nigeria
}

\author{
R. C. Egbuobi1 ${ }^{*}$, M. A. Nwagbaraocha1', J. N. Dike-Ndudim¹, H. M. Okorie1, I. A. Ogamaka ${ }^{2}$, \\ L. N. Egbuobi ${ }^{3}$, P. C. Enwuru', J. E. Ereh ${ }^{5}$ \\ ${ }^{1}$ Department of Medical Laboratory Science, Imo State University, Owerri, Nigeria \\ ${ }^{2}$ Department of Microbiology, Imo State University, Owerri, Nigeria \\ ${ }^{3}$ Public Health Laboratory, Ministry of Health, Owerri, Nigeria \\ ${ }^{4}$ St. John's Medical Laboratory, Owerri, Nigeria \\ ${ }^{5}$ Hospital Management Board, Ministry of Health, Owerri, Nigeria \\ Email: neekyrichy@yahoo.com
}

Received 28 November 2013; revised 30 December 2013; accepted 6 January 2014

Copyright (C) 2014 by authors and Scientific Research Publishing Inc.

This work is licensed under the Creative Commons Attribution International License (CC BY). http://creativecommons.org/licenses/by/4.0/

(c) (i) Open Access

\section{Abstract}

Incidence of intestinal Parasites has been described as one of the most common problems of developing countries like Nigeria. World Health Organization estimated that 3.5 billion people worldwide are infected with some types of intestinal parasites, and as many as $\mathbf{4 5 0}$ million of them are sick as a result. This work therefore is carried out to access the carrier status of food handlers around the University of Nigeria Teaching Hospital Enugu in Enugu State of Nigeria as well as to ascertain the common offending parasite. Three hundred and six (306) stool samples were randomly collected between January and August, 2001 from food vendors occupying the zones around the Teaching Hospital which include: UNTH Road, Railway track, Prison old park and Dean's cook. The samples were transported to the University of Nigeria Teaching Hospital Parasitology Laboratory within 1 hour of production and analysed Parasitologically using Physiological saline and iodine direct mount and formal ether concentration techniques. Out of the 306 stool samples analysed, 126 representing $41.2 \%$ tested positive to parasites. Entamobe histolytica showed the highest incidence of $\mathbf{5 2 . 4 \%}$ followed by Ascaris lumbricoidis with $23.8 \%$ and the least was Tricharis trichura with $40 \%$. The incidence of mixed infection was $44.4 \%$. Female food handlers were more infected $44.2 \%$ than the male food handlers $36.8 \%$. Whereas Meat handlers were most infected $66.7 \%$ among other food handlers. From the result of the work, it can be inferred

\footnotetext{
${ }^{*}$ Corresponding author.
}

How to cite this paper: Egbuobi, R.C., et al. (2014) Incidence of Intestinal Parasites among Food Handlers (Hawkers) around the University of Nigeria Teaching Hospital Enugu, Enugu State, Nigeria. Open Journal of Medical Microbiology, 4, 23-28. 
that the incidence of intestinal parasites among food handlers around the University of Nigeria Teaching Hospital Enugu is high and this can be attributed mainly to poor sanitary condition of this area. We therefore recommend that Enugu State Government should intensify her sanitation programme especially where public foods are being handled, as well as provide enlightenment campaign for food handlers to save the lives of her citizenry.

\section{Keywords}

\section{Parasite; University; Hospital; Teaching; Sanitary; Helminthes}

\section{Introduction}

The incidence of intestinal parasites is one of the most common problems of the developing countries like Nigeria. The World Health Organization (WHO) estimated that 3.5 billion people worldwide are infected with some types of intestinal parasites and as many as 450 million of them are sick as a result, with the majority being children [1].

Intestinal parasites are parasites that populate the gastro-intestinal tract in humans and other animals [2]. They can live throughout the body, but most prefer the intestinal wall. Means of exposure include, ingestion of undercooked meat, drinking infected water and skin absorption. The two main types of intestinal parasite are helminthes and protozoa. And intestinal parasite can damage or sicken its host [3].

Helminthes are multicellular parasitic worm which causes intestinal infection initiated by ingestion of helminthic ova or penetration of skin by infectious larvae. Human intestinal helminthes are among the common infection occurring throughout the developing countries [4]. Many parasitic infections especially those of helminthic origins are asymptomatic and could produce mild or in a typical case confusing symptoms and often neglected until bizarre, serious or chronic clinical features are present. In most rural countries, economic condition is obvious predisposing factors to high prevalence of human intestinal helminthiasis [5].

Gastrointestinal parasites flourish where poverty prevails, where sanitation is inadequate or non-existent and where more health awareness is needed [6]. These parasites remain the major causes of morbidity, especially among children in the developing countries [7]. Among the effects associated with these parasites are growth retardation. Intestinal obstruction, hepatic and biliary disease, impaired cognitive development and nutritional effect such as iron deficiency or anemia [8].

Six intestinal helminthes that commonly infect humans are Enterobius vermicularis (Pinworm), Trichuris trichura (Whipworm), Ascaris lumbricoidis (Roundworm), Necator americanus and Ancylostoma duedenale (Hookworm) and Strongyloides starcoralis.

Numerous protozoa inhabit the gastrointestinal tract of humans. This list includes representative from many diverse protozoa groups. The majority of these protozoa are non-pathogenic commensals or only result in mild disease under certain circumstances [9].

Waste water reuse may lead to public health risk of transmission of endemic health parasitic disease following consumption of raw vegetables. It may also result in the transmission of endemic parasitic disease that mostly strike children [10]. Intestinal protozoa are transmitted by the faecal-oral route and tend to exhibit similar life cycles consisting of a cystic and trophozoite stages. Factors which increase the likely-hood of ingesting materials contaminated with faecal materials, play a role in the transmission of the intestinal protozoa. In general, situation involving close human to human contact and unhygienic conditions promote transmission [11]. Helminthes are transmitted by eggs present in human faeces which in turn contaminate soil, water or food in areas where sanitation is poor. It is common practice in Nigeria to see people eating in small canteens and patronizing mobile food vendors. This, they do due to lack of time to cook, the need to quench hunger as fast as possible and so many other reasons [12] and more than 200,000 persons die of food poison in Nigeria annually [13].

This work therefore is primarily aimed at finding out the carrier status of the population of food vendors around University of Nigeria Teaching Hospital Enugu, as well as the common offending parasites and proffer solution where necessary. 


\section{Materials and Methods}

\subsection{Study Area/Population}

The study area is University of Nigeria Teaching Hospital Enugu in Enugu State of Nigeria. Enugu is located at the South Eastern part of Nigeria. It lies within latitude $6.4527^{\circ} \mathrm{N}$ and longitude $7.5103^{\circ} \mathrm{E}$. It has an estimated population of 1.2 million inhabitants and above. It is bounded in the West by Anambra State, in the North by Benue State in the East by Abia State and in the South by Ebonyi State. The University Teaching Hospital community has many small eateries managed by food vendors of different kinds. These canteens are situated at areas like University of Nigeria Teaching Hospital (UNTH) road, Railway track, Prison old park and Den’s cook.

\subsection{Sample Collection}

A total of 306 stool samples were collected between January and August, 2001 from different food vendors occupying different zones around the University Teaching Hospital, such as UNTH road, Railway track, Prison old park, and Den's cook. The samples were randomly collected from both male and female vendors after obtaining their permission to do so. Oral questionnaires were used as a source of data collection about their names, the type of food they are handling, their source of water supply and toilet facilities.

The subjects were each given clean, dry, leak-proof well labeled wide mouthed specimen bottle with screwed cap. They were instructed on how to collect their stool samples into the containers. The samples were transported to University of Nigeria Teaching Hospital Parasitology laboratory within 1 hour of production for analysis.

\subsection{Laboratory Analysis}

Generally, macroscopic reports of the stool samples were given in terms of colour, consistency, odor, presence of blood or mucus and presence of adult worm. However, the microscopic examination of stool was based on the following methods.

\subsubsection{Direct Wet Preparation}

A drop of freshly prepared physiological saline was placed on one slide and a drop of Dobells iodine on the other slide. Using an applicator stick, a small amount of the specimen about $1 \mathrm{~g}$ (matchstick head amount) was smeared with the saline and a similar amount with the iodine. The smooth thin preparations were covered with cover glass. And the entire saline preparation was systematically examined for larvae, ciliates, helminthes eggs, cysts and oocysts using 10× objective with condenser iris closed sufficiently to give good contrast, while 40× objective was used to assist in the detection and identification of eggs, cysts and oocysts. Iodine preparation was used to assist in identification of cysts [14].

\subsubsection{Formol Ether Concentration Techniques}

An estimated $1 \mathrm{~g}$ of formed stool sample or $2 \mathrm{ml}$ of watery stool was emulsified in about $4 \mathrm{ml}$ of $10 \%$ formol water contained in a screw-cap bottle. A further $3 \mathrm{ml}$ of $10 \%$ formol water was added and mixed well by shaking. The emulsified faeces was sieved through a coffee strainer and the sieved suspension transferred to a conical (centrifuge) tube made of strong glass, polypropylene. $3 \mathrm{ml}$ of diethyle ether was added and the tube was stoppered mixed for 1 minute with a tissue wrapped around the top of the tube, the stopper was loosen. It was then centrifuged at 3000 rpm for 1 minute. Using a stick, the layer of faeces debris from the side of the tube was loosen and the tube inverted to discard the ether, faecal debris, and formol water leaving behind the sediment. The tube was returned to its upright position and the fluid from the sides of the tube allowed draining to the bottom. The bottom of the tube was taped to re-suspend and mix the sediment. The sediment was transferred to a slide and covered with a cover glass and examined microscopically using the 10x objective for focusing and 40× objective for proper identification [14].

\section{Result}

The result of the incidence of intestinal parasites among food handlers around the University of Nigeria Teach- 
ing Hospital Enugu, Enugu State, Nigeria are as follows; after examining total of three hundred and six (306) stool samples microscopically for intestinal parasites.

Table 1 shows the incidence of intestinal parasites according to zones. Den's cook zone showed the highest incidence 19 (45.3\%) followed by Prison old park 44 (43.1\%), the least incidence 12 (33.3\%) was recorded by UNTH road.

Table 2 shows the incidence of mixed infections in different zones. The incidence was 56 (44.4\%). UNTH road produced the highest incidence of 7(58.3\%) while the mixed infections were more of (Hookworm and Entamoba histolytica) and (Hookworm, Ascaris and Entamoba histolytica) which has incidence of (29.1\%) each. The lowest incidence $1(1.8 \%)$ in this category was recorded by Trichuris trichura and Entamoba histolytica.

Table 3 shows the incidence of intestinal parasites according to sex. Females were shown to be more infected $80(44.2 \%)$ as against their males counterpart with incidence of $46(36.8 \%)$.

Table 4 shows the incidence of intestinal parasites according to food. Meat handlers were more infected with incidence of 8 (66.7\%), followed by Okpa handlers 15 (50.0\%). The lowest were the snacks handlers 30 (35.7\%).

\section{Discussion}

This work was carried out to access the parasitic carrier status of the population of food vendors around the University of Nigeria Teaching Hospital Enugu, in Enugu State, Nigeria. It was also carried to ascertain the common offending parasites as well as to proffer solutions on how to minimize, if not to eradicate the bug.

Observations from the result of this work shows that (41.2\%) of the test population was infested with one intestinal parasites or the other. This high incidence could be as a result of the poor financial condition of these

Table 1. Incidence of intestinal parasites according to zones.

\begin{tabular}{ccccccc}
\hline \multicolumn{1}{c}{ Zones } & $\begin{array}{c}\text { No. of samples } \\
\text { collected }\end{array}$ & $\begin{array}{c}\text { No. of handlers tested } \\
\text { positive to parasite }\end{array}$ & $\begin{array}{c}\text { Percentage (\%) } \\
\text { of Hookworm }\end{array}$ & $\begin{array}{c}\text { Percentage (\%) } \\
\text { of Ascaris }\end{array}$ & $\begin{array}{c}\text { Percentage (\%) } \\
\text { of } \text { T. trichura }\end{array}$ & $\begin{array}{c}\text { Percentage (\%) } \\
\text { of E. histolytica }\end{array}$ \\
\hline Prison old park & 102 & $44(43.1)$ & $10(22.7)$ & $14(31.8)$ & - & $20(45.5)$ \\
Railway Track & 126 & $51(40.5)$ & $6(11.8)$ & $16(31.4)$ & $5(9.8)$ & $24(47.1)$ \\
UNTH Road & 36 & $12(33.3)$ & $2(16.7)$ & - & - & $10(83.3)$ \\
Den's cook & 42 & $19(45.3)$ & $7(36.8)$ & - & - & $12(63.2)$ \\
Total & 306 & $126(41.2)$ & $25(19.8)$ & $30(23.8)$ & $5(4.0)$ & $66(52.4)$ \\
\hline
\end{tabular}

Table 2. Incidence of co-infection in different zones.

\begin{tabular}{|c|c|c|c|c|c|c|c|c|c|}
\hline Zones & $\begin{array}{c}\text { No. of } \\
\text { samples } \\
\text { collected }\end{array}$ & $\begin{array}{l}\text { No. of handlers } \\
\text { tested positive } \\
\text { to parasite }\end{array}$ & $\begin{array}{c}\text { \% of } \\
\text { multiple } \\
\text { infections }\end{array}$ & $\begin{array}{l}\text { \% Hookworm } \\
\text { \& Ascaris }\end{array}$ & $\begin{array}{l}\text { \% Hookworm } \\
\text { \& E. histo }\end{array}$ & $\begin{array}{l}\text { \% Ascaris } \\
\text { \& E. histo }\end{array}$ & $\begin{array}{l}\text { \% Hookworm } \\
\text { \& T. trichura }\end{array}$ & $\begin{array}{l}\text { \% T.tuch } \\
\text { \& E. histo }\end{array}$ & $\begin{array}{c}\text { \% Hookworm, } \\
\% \text { Hookworm, \& } \\
\text { E. histo }\end{array}$ \\
\hline $\begin{array}{c}\text { Prison } \\
\text { old park }\end{array}$ & 102 & 44 & 17 (38.6) & $4(23.5)$ & $6(35.3)$ & 4 (23.3) & - & - & $3(17.7)$ \\
\hline $\begin{array}{l}\text { Railway } \\
\text { Track }\end{array}$ & 126 & 51 & $22(43.1)$ & $2(9.1)$ & $4(18.2)$ & $10(45.5)$ & $1(4.6)$ & $3(13.6)$ & $2(9.1)$ \\
\hline $\begin{array}{l}\text { UNTH } \\
\text { Road }\end{array}$ & 36 & 12 & $7(58.3)$ & - & 2 (28.6) & - & - & - & $5(71.4)$ \\
\hline $\begin{array}{l}\text { Den's } \\
\text { cook }\end{array}$ & 42 & 19 & $10(52.6)$ & - & $4(40.0)$ & - & - & - & $6(60.0)$ \\
\hline Total & 306 & 126 & $56(44.4)$ & $6(10.9)$ & 16 (29.1) & 14 (25.5) & $1(1.8)$ & $3(5.5)$ & 16 (29.1) \\
\hline
\end{tabular}

Table 3. Incidence of intestinal parasites according to sex.

\begin{tabular}{|c|c|c|c|c|c|c|}
\hline Sex & $\begin{array}{c}\text { No. of samples } \\
\text { collected }\end{array}$ & $\begin{array}{l}\text { No. of handlers tested } \\
\text { positive to parasite }\end{array}$ & $\begin{array}{l}\text { Percentage (\%) } \\
\text { of Hookworm }\end{array}$ & $\begin{array}{c}\text { Percentage (\%) } \\
\text { of Ascaris }\end{array}$ & $\begin{array}{c}\text { Percentage (\%) } \\
\text { of } T \text {. trichura }\end{array}$ & $\begin{array}{l}\text { Percentage (\%) } \\
\text { of E. histolytica }\end{array}$ \\
\hline Male & 125 & 46 (36.8) & 11 (23.9) & $10(21.7)$ & $2(4.4)$ & $20(43.5)$ \\
\hline Female & 181 & $80(44.2)$ & 14 (17.5) & $20(25.0)$ & 3 (3.8) & 46 (57.5) \\
\hline
\end{tabular}


Table 4. Incidence of intestinal parasites according to types of food.

\begin{tabular}{ccccccc}
\hline Food category & $\begin{array}{c}\text { No. of samples } \\
\text { collected }\end{array}$ & $\begin{array}{c}\text { No. of handlers tested } \\
\text { positive to parasite }\end{array}$ & $\begin{array}{c}\text { Percentage (\%) } \\
\text { of Hookworm }\end{array}$ & $\begin{array}{c}\text { Percentage (\%) } \\
\text { of Ascaris }\end{array}$ & $\begin{array}{c}\text { Percentage (\%) } \\
\text { of } \text { T. trichura }\end{array}$ & $\begin{array}{c}\text { Percentage (\%) } \\
\text { of E. histolytica }\end{array}$ \\
\hline Cooked food & 180 & $73(40.5)$ & $16(21.9)$ & $18(24.7)$ & $4(5.5)$ & $35(48.0)$ \\
Okpa & 30 & $15(50.0)$ & $3(20.0)$ & $3(20.0)$ & - & $9(60.0)$ \\
Snacks & 84 & $30(35.7)$ & $5(16.7)$ & $6(20.0) 1$ & $1(3.3)$ & $18(60.0)$ \\
Meat & 12 & $8(66.7)$ & $1(12.5)$ & $3(37.5)$ & - & $4(50.0)$ \\
\hline
\end{tabular}

food handlers as well as poor sanitary condition of the environment in which they transact their business (Teaching Hospital environment). This is in agreement with [6] who maintains that gastrointestinal parasites flourish where poverty prevail, where sanitation is inadequate or non-existent and where health awareness is needed.

It was also observed that the incidence of Entamoba histolytica was highest (52.4\%) among the identified parasites, followed by Ascaris (23.8\%) and Hookworm (19.8\%). This can also be attributed to a poor sanitary condition as well as inadequate portable water supply to the Teaching Hospital environment. From the oral questionnaire obtained, it was obvious that water supply to the Teaching Hospital environment and Enugu in general was inadequate, hence people resorted to ponds, wells, streams, rivers and tanker water supply as their alternative source of water supply. In response to this water scarcity, waste water reuse became the order of the day. This is in agreement with [10] who stated that waste water reuse may lead to public health risk of transmission of endemic health parasitic disease, following consumption of raw vegetables. It may also result in the transmission of endemic parasitic disease that mostly strike children. This is also in agreement with [15], who stated that intestinal parasites are more common in tropical countries or other areas with poor sanitary conditions.

The high incidence among handlers within Den's cook zone can be attributed to lack of adequate toilet facilities in the areas which created a room for indiscriminate defication/disposal of faeces around the area. This is in agreement with [16] who attributed presence of these parasites in a study area as a suggestion that the prevailing environmental and ecological condition support the transmission of wide range of those parasites.

The high rate $(44.4 \%)$ of Co-infection is a confirmation of poor sanitary condition of the environment under study. Refuse disposal system according to the response of our oral questionnaire is indiscriminate, and collection by government agents not regular. This agrees with [17] who attributed such a high rate of mixed infection to a confirmation of the fact that parasitic disease transmission depend upon poor environmental condition including indiscriminate disposal of feaces and personal hygiene.

Females recorded a higher incidence of (44.2\%) than the male counterpart (36.8\%). This can be due to the fact that women are much more involved in kitchen work than men. Most of the males participate in the selling of the already prepared food, while women are those who go bare footed during the preparation of the food, as well as those who do the washings of vegetables and fruits. This is in agreement with [18] who incriminated intestinal nematodes transmission to humans to be due to either ingestion of soil contaminated with infective eggs e.g. Ascaris lumbricoidis and Trichuris trichura or penetration of skin with infective larvae, e.g. Hookworm and Strongyloidis starcoradis.

The high incidence (66.7\%) recorded among meat handlers can be attributed to the poor hygienic condition of the Enugu abattoirs as well as the poor or inadequate water supply to the environment under the study, lack of maintenance of personal hygienic standards by the handlers who do not take proper bath as a result of water scarcity. This collaborate with11 who attributed intestinal parasitic transmission to poor environmental condition including indiscriminate disposal of feaces and personal hygiene.

\section{Conclusions/Recommendations}

In conclusion, this research work has confirmed that the incidence of intestinal parasitic infection among food handlers around University of Nigeria Teaching Hospital Enugu in Enugu State is high and dependent on mainly factors aforementioned.

Considering the threat this high rate poses to human life, appeal to Enugu State Government to improve in the water supply to this area, and enlightenment campaign be organized to educate the food handlers on personal 
hygiene standard.

Finally, Government agencies such as National Agency for Food and Drug Administration and Control (NAFDAC) should rise up to their duty of ensuring proper food handling Nationwide.

\section{References}

[1] WHO (1987) Prevention and Control of Intestinal Parasitic Infections. Report of WHO. Expert Countries. Technical Report Service 749, World Health Organization, Geneva.

[2] Loukpoulos, P., Komnenou, A., Papadopoulos, E. and Psychas, V. (2007) Lethal Ozolaimus Megatyphlon Infection in a Green Iguana (Iguana Iguana Rhinolopa). Journal of Zoo and Widelife Medicine, 38, 131-134.

[3] Daniel, J. (2007) Cleanse and Purify Thyself Book One. Christobe Publishing, Medford.

[4] Agbolade, O.M., Akinboye, D.O. and Awolaja, A. (2004) International Helminthiasis and Urinary Schistosomiasis in Some Village of Ijebu North, Ogun State, Nigeria. Africa Journal of Biotechnology, 3, 206-209.

[5] Gundiri, M.A. and Akogun, O.B. (2000) Gastrointestinal and Urinary Parasitic Infection amongst School Children in Rundeyelu. Nigeria Journal of Parasitology, 21, 117-124.

[6] Dada, E.O. and Erinle, B.A. (2004) Study of Human Gastrointestinal Parasite among Primary School Children in Ibule South Community of Ifedole Local Government Area of Ondo State, Nigeria. Journal of Medical Laboratory Science, 13, 62-65.

[7] Wani, S.A., Ahmad, J., Zanga, S.A., Fomda, B.A., Ahmad, Z. and Ahmad P.H. (2007) Helminthic Infection in Children of Kupwuara District. A Prospective Study. Industrial Journal of Medical Microbiology, 25, 395-400.

[8] Simeon, D.I., Granthan, M.C., Gregor, S.M., Callanda, J.G. and Wong, M.S. (2000) Treatment of Trichuris trichura Infection Improves Growth. Spelling Sores and School Attended in Some Children. Journal of Nutrition, 125, 875-883.

[9] Egbuobi, R.C., Dike-Ndudim J.N., Nwagbaraochaa M.A. and Nnodim J.K. (2013) Intestinal Parasitic Infection among Pupils in Umuezeaga Autonomous Community, Akokwa in Ideato North Local Government Area, Imo State, Nigeria. International Research on Medical Science, 1, 006.

[10] Habari, K., Tifnouti, A., Bitton, G. and Mandil, A. (1999) Helminthic Infections Associated with the Use of Raw Waste for Agricultural Purposes in Beni Mehal; Morocco. Eastern Meditenamean. Health Journal, 5, 912-921.

[11] Prota, A. (2001) Clinical and Epidemiological Aspect of Chagas Disease. Lancet infectious Disease, 1, 92-100. http://dx.doi.org/10.1016/S1473-3099(01)00065-2

[12] Tolulope, L. (2010) Poor Hygiene: Canteens and Food Vendors in Nigeria. http://new2onlinenigeria.com

[13] Ihenkuronye (2012) 200,000 Peoples Die of Food Poison Annually in Nigeria. The Premium Times Nigeria. http://premiumtimesng.com

[14] Cheesbrough, M. (2000) District Laboratory Practice in Tropical Countries. Part 1, Lower Price Edition, Edinbough Building UK, 193-198.

[15] Maegraith, B., Brown, S.G., Gilles, H.M. and Reid, H.A. (1978) Aden and Maegraith Clinical Tropical Disease. 6th Edition, Black-Well, Oxford.

[16] Rufai, A.M. and Awi, W.G.D.B. (2006) Prevalence of Human Gastrointestinal Parasitic Infections in Relation to Human and Industrial Activities in Ramuoluemi Community, Rivers State. African Journal of Applied Zoology \& Environmental Biology, 8, 62-66.

[17] Ikon, G.M. and Useh, M.F. (1979) Epidemiology of Gastrointestinal Helminthic among Pupils in Urban and Sub-Urban Communities in Nigeria. Journal of Medical Laboratory Science, 8, 1-6.

[18] Gary, P.K., Pany, S. and Dorn, M. (2005) Risk of Intestinal Helminthic and Protozoa Infection in a Refuge Population. American Journal of Tropical Medical Hygiene, 73, 386-391. 